\title{
Do Efficiency Ratios Help Investors to Explore Firm Performances? Evidence from Italian Listed Firms
}

\author{
Pierluigi Santosuosso ${ }^{1}$ \\ ${ }^{1}$ School of Economics, Sapienza University of Rome, Rome, Italy \\ Correspondence: Pierluigi Santosuosso, School of Economics, Sapienza University of Rome, Rome, Italy. Tel: \\ 39-6-4976-6460. E-mail: pierluigi.santosuosso@uniromal.it
}

Received: October 16, 2014

Accepted: November 10, 2014

Online Published: November 25, 2014

doi:10.5539/ibr.v7n12p111

URL: http://dx.doi.org/10.5539/ibr.v7n12p111

\begin{abstract}
This paper examines how proxies of efficiency can help investors in exploring firm profitability, stock market value and operational cash flow using company accounting information on the basis of the multiple regression model. On a sample of 215 non-financial firms listed on the Italian Stock Exchange between 2004 and 2013, a positive correlation was found between several turnover ratios used as proxies of efficiency and measures of firm profitability that are more closely related to operating activities such as EBITDA to assets ratio. Similarly, a positive correlation was revealed when operational cash flow was examined, whilst no significant associations between proxies of efficiency and stock market indicators were found. Furthermore, this study explored the role that turnover ratios used as proxies of efficiency have on capital structure in order to gain insight into the significance of relationships related to cash flow.
\end{abstract}

Keywords: efficiency, turnover ratios, financial analysis, Italian firms

\section{Introduction}

Over the last years, many studies have analysed the measurement of efficiency and the relationship between efficiency and several variables such as firm profitability, managerial ability, organizational performances, firm size, capital structure, stock return etc. Researchers have examined these issues using different concepts of efficiency (e.g. technical efficiency, productive efficiency, profit efficiency and X-efficiency) and various research methodologies (financial analysis, data envelopment and stochastic frontier analysis) for manufacturing (Alam \& Sickles, 1998; Becchetti \& Sierra, 2003), insurance (Greene \& Segal, 2004; Cummins \& Xie, 2009; Gaganis, Hasan, \& Pasiouras, 2013) and in particular for banking companies (e.g. Berger \& Humphrey, 1992; Barr et al., 2002; Akhigbe \& McNulty, 2005; Berger \& Bonaccorsi di Patti, 2006) on the basis of data collected in countries around the world. The variety of issues explored by these studies has long been highlighted by researchers (Berger \& Mester, 1997) and described in more recent studies (Baik et al., 2013).

One main question that has been raised about efficiency concerns its relationship with firm profitability. Specifically, a positive relationship between efficiency and profitability was found using different techniques, such as Data Envelopment Analysis and Stochastic Frontier Analysis, by Barr et al. (2002) for U.S. commercial banks, Greene and Segal (2004) for the U.S. life insurance industry and Baik et al. (2013) for a sample across multiple industries. The connection between efficiency and profitability has been also studied using other methods such as the well-known "DuPont system" which allows analysts to examine firm profitability by decomposing ROE into profit margin, asset turnover and financial leverage (e.g. Fairfield \& Yohn, 2001; Soliman, 2008). Moreover, there has been an increasing interest in examining the relationship between efficiency and stock market performance. More specifically, on the basis of linear programming, Alam and Sickles (1998) found a significant association between efficiency news in one quarter and stock market performance in the following two months for the US Airline industry. Gaganis, Hasan and Pasiouras (2013) reported a similar positive relationship in listed insurance firms in 52 countries. The issue was developed further by analyzing the portfolio composed of efficient firms and the portfolio of inefficient firms. Although research revealed that the most efficient firms seem to have higher risks than inefficient firms, unambiguous results emerged about the performance of portfolios over time (Nguyen \& Swanson, 2009; Frijns, Margaritis, \& Psillaki, 2012). The relationship between efficiency and firm performances, measured by various proxies and analysed with different approaches, has also been addressed by focusing on several specific issues such as agency costs in publicly held 
corporations (Habib \& Ljunqvist, 2005), firm size (Halkos \& Tzeremes, 2007), service quality (Talluri, Kim, \& Schoenherr, 2013) and managerial ability (Demerjian, Lev, \& McVay, 2012).

Despite the variety of concepts of efficiency, this study does not examine a specific notion of efficiency and its possible measure, but uses financial ratios that are available for investors and commonly interpreted as proxies of efficiency in line with the methodology adopted by financial analysis. The research question we address here is whether the analysis of efficiency ratios (e.g. the asset turnover ratio) can help investors and equity analysts to explore firm performances on the basis of the most widely used methodology, namely the multiple regression model. In other words, relationships between proxy variables were analysed in this research using the OLS regression model as research methodology in order to ascertain whether a common technique can help investors and equity analysts to identify firm performances using annual report information. Accounting quantity variables and other qualitative measures derived from the narrative section of annual reports are widely used for processing equity analyses (Bouwman, Frishkoff, \& Frishkoff, 1995; Rogers \& Grant, 1997; Breton \& Taffler, 2001; Kothari, 2001) on the basis of a common forecasting method (e.g. Makridakis, Wheelwright, \& Hyndman, 1998) and exposed in stock recommendation reports (Abdolmohammadi et al., 2006). The relevance of this information for investors has become especially important during the recent economic crisis in which cost reduction, and therefore the need for increasing efficiency, has played a significant role in responses to financial and economic distress, even before adopting measures such as divestment of current and non-current assets, equity issuance and debt restructuring (e.g. John, Lang \& Netter, 1992; Robbins \& Pearce, 1992; Kang \& Shivdasani, 1997; Sudarsanam \& Lai, 2001; Jiang \& Wang, 2009).

Using a sample made up of 215 non-financial firms listed on the Italian Stock Exchange between 2004 and 2013 for a total of 1,935 firm-year observations, we analysed several proxy variables for efficiency and firm performances. More specifically, this paper examines various measures of firm profitability, stock market value and operational cash flow as dependent variables and some financial ratios that are frequently used as proxies of efficiency as explanatory variables such as the Assets turnover, Inventory turnover, Accounts receivable turnover ratio and Revenue per employee. We assume that efficiency is a driver of firm profitability, as stated by the DuPont system, and profitability can also positively affect, ceteris paribus, the amount of cash flow and stock prices as well. The examination of these relationships has also led our study to explore the role that efficiency has on firms' capital structure in order to gain insight into the significance of relationships in particular related to cash flow. To date, this topic has received little attention by the research literature (Berger \& Bonaccorsi di Patti, 2006; Margaritis \& Psillaki, 2007; Norvaisiene, 2012). Berger and Bonaccorsi di Patti (2006) analyzed profit efficiency and capital structure for the US banking industry. Using Data Envelopment Analysis, Margaritis and Psillaki (2007) found that the efficiency of 12,240 New Zealand firms has a positive effect on leverage at low to mid-leverage levels and a negative effect at high leverage ratios. Norvaisiene (2012) focused on the reverse causality from capital structure to efficiency.

We therefore expect that investors and equity analysts are able to find a positive association between turnover ratios and several proxy variables for firm profitability, stock market value and operational cash flow. To examine this hypothesis, the analysis is organized as follows: the second section provides data, sample selection and methodology; the third section presents the results; the last section exposes the concluding remarks.

\section{Firm Sample and Methodology}

The sample examined in this study contains 1,935 firm-year observations on 215 Italian listed firms between 2004 and 2013. We excluded from the sample banks, finance and insurance companies. Data were not necessarily acquired for all firms throughout the period 2004-2013 since some companies were not listed for the entire period and/or data were not provided completely by the data provider. Therefore, for each regression analysis between proxy variables examined here, there may be a fewer than 1,935 firm-year observations. On the basis of these limitations, the firm sample covers all non-financial companies on the Italian Stock Exchange. Financial statement information and stock prices on the sample of firms were obtained from DataStream.

We identified several proxies of efficiency as independent variables using financial statement information. This study examined the Total asset turnover (sales to average total assets ratio), Inventory turnover (sales to average inventory ratio), Accounts receivable turnover (sales to average account receivable ratio) and Revenue per employee (sales to the number of employees). The denominator of these ratios was computed in our study as the average between the opening and the closing value. Therefore, data collected for the period 2004-2013 were used to calculate the average value for the period 2005-2013.

Several studies have examined efficiency using such proxy variables. Among others, Lev and Thiagarajan (1993) underlined the value-relevance of a set of financial variables over earnings, including sales-per-employee. 
Fairfield and Yohn (2001) examined how components of return on assets used in the DuPont analysis (namely, Asset turnover and Profit margin) are relevant in forecasting change in future earnings whilst Soliman (2008) focused on how equity analysts and investors use these components by analysing equity returns. Jansen, Ramnath and Yohn (2012) considered Asset turnover and Profit margin for identifying earnings management, Kwak (2013) examined the relationships between the implementation of information technology and inventory turnover and Alan, Gao and Gaur (2014) analysed whether inventory productivity can predict future stock returns. Many other studies from academics and practitioners explored the descriptive power of turnover ratios (e.g. Gupta \& Huefner, 1972; Koly \& Rawat, 2011).

Although these ratios are frequently used by analysts, it is still difficult to identify the concept of efficiency they can measure. Several concepts of efficiency and various measuring systems have been developed over the last century. Some main notions of efficiency used in the business context are technical efficiency (Koopmans, 1951), productive efficiency (Farrell, 1957), allocative and X-efficiency (Leibenstein, 1966), cost and profit efficiency (Berger \& Mester, 1997). For example, asset turnover ratios do not exactly measure productive efficiency, since its computation needs detailed figures on the amount of products expressed in different units of measurement such as the number of products, kilograms, litres and the cost of production for each type of good and service produced by a firm. Similarly, asset turnover ratios do not even express the concept of profit efficiency, since it denotes the distance between the profit obtained by a firm and the maximum profit achievable in the case of optimum efficiency (Berger \& Mester, 1997). Whatever the concept to explore, it is obvious that data available to investors and analysts do not provide many kinds of information about firms' performances. Generally, Turnover ratios refer approximately to the company's ability to employ its resources within the limits of the explanatory power of accounting information.

Aware of these limits, this study examined the correlations between the above mentioned turnover ratios and the following three sets of financial ratios as dependent variables using the OLS regression model.

First, we identified EBITDA to total assets, Return on assets (ROA) and Return on equity (ROE) as proxies of profitability in order to explore the relationship between proxies of efficiency and firm profitability. In particular, we expected a positive relationship between these variables and proxies of efficiency. However, it is likely that the significance of regression results relating to each dependent variable will differ from each other since EBITDA to asset ratio, ROA and a fortiori ROE are progressively less dependent on factors that could affect efficiency and increasingly influenced by many other firm and market variables.

Second, the association between proxies of efficiency and stock market value were explored using Market-to-book ratio (market capitalization to book value of shareholders' equity), Price to earnings ratio (market capitalization to earnings after taxes) and Market to sale ratio (market capitalization to total revenues). The analysis was carried out on the assumption that efficiency, measured by asset turnover ratios, is a driver of firm profitability and profitability can affect stock prices as well.

Third, to gain insight into a possible association between proxies of efficiency and cash flow, we considered the following financial ratios: the Cash flow to total assets ratio (cash flow from operation divided by total assets), the Cash flow to debt ratio (cash flow from operations divided by total financial debt) and the Cash flow to account payable ratio (cash flow from operation divided by total account payable). These ratios provide respectively an indication of the amount of cash flow from operations the firm has available for investing in assets and the firm's capability to cover its total debt and account payable with operating cash flow. The inclusion of debt and account payable in the explanatory variables has led us to explore the role of some components of firms' capital structure in order to have a better knowledge of the significance of some relationships found on the basis of regression analysis. To enhance the understanding of this issue, the relationship between proxies of efficiency and Total liabilities to assets ratio, Account payable to total liabilities ratio, Debt to total liabilities and Long-term debt to total debt ratios were examined.

The small number of firms listed on the Italian stock exchange did not allow us to examine significantly the above mentioned relationships by dividing companies according to industry. On the basis of the Thomson Reuters Business Classification (TRBC), the firm sample in this study covers 72 "industries" (the fourth level of industry classification). Or to be more precise, the average number of firms for each industry is 2.94 , the median is 2 and the maximum number is 14 (Apparel \& Accessories).

\section{Results}

As described in Table 1, the regression analysis between proxies of efficiency and firm profitability revealed that managers' efforts to increase efficiency are mainly reflected in the EBITDA to assets ratio. Except for the Revenues per employee, all turnover ratios used in the analysis proved to have a positive and significant 
explanatory power on the EBITDA to assets ratio. Moreover, the Total asset turnover showed a positive strong relationship with ROA, whilst a weak association was found with ROE. The positive relationship between Asset turnover ratio and a firm's return on operating assets was highlighted by other studies (Fairfield \& Yohn, 2001; Nissim \& Penman, 2001; Soliman, 2008) and several surveys have also underlined the positive association between firm profitability and efficiency on the basis of Data Envelopment Analysis and Stochastic Frontier Analysis (for a review, Baik et al., 2013). As predicted, regression results seem to be consistent with the hypothesis that the measures of firm profitability more closely connected to operating activities, such as EBITDA to assets ratio, are strictly dependent on factors that affect efficiency. The Variable Inflation Factor (VIF) was used to test the multicollinearity. The test did not reveal a multicollinearity problem, as shown by the VIF of each of the following independent variables: Total asset turnover (1.41), Inventory turnover (1.003), Accounts receivable turnover (1.065) and Revenue per employee (1.077).

Table 1. Profitability and efficiency

\begin{tabular}{|c|c|c|c|c|c|}
\hline EBITDA to assets & Estimate & StdError & $\mathrm{z}$ value & $\operatorname{Pr}(>|z|)$ & \\
\hline Const & 0,0245306 & 0,00599782 & 4,0899 & 0,00005 & $* * *$ \\
\hline Total asset turnover & 0,0706392 & 0,00686123 & 10,2954 & $<0,00001$ & $* * *$ \\
\hline Inventory turnover & $2,58706 \mathrm{e}-05$ & $1,26471 \mathrm{e}-05$ & 2,0456 & 0,04097 & $* *$ \\
\hline Accounts receivable turnover & 0,00113496 & 0,000439375 & 2,5831 & 0,00989 & $* * *$ \\
\hline Revenue per employee & $-3,36392 \mathrm{e}-06$ & $3,79276 \mathrm{e}-06$ & $-0,8869$ & 0,37526 & \\
\hline ROA & Estimate & StdError & $\mathrm{z}$ value & $\operatorname{Pr}(>|z|)$ & \\
\hline Const & $-0,0192112$ & 0,00598482 & $-3,2100$ & 0,00136 & $* * *$ \\
\hline Total asset turnover & 0,0742518 & 0,00684637 & 10,8454 & $<0,00001$ & $* * *$ \\
\hline Inventory turnover & $1,59159 \mathrm{e}-05$ & $1,26197 \mathrm{e}-05$ & 1,2612 & 0,20744 & \\
\hline Accounts receivable turnover & 0,000706185 & 0,000438423 & 1,6107 & 0,10745 & \\
\hline Revenue per employee & $-2,96521 \mathrm{e}-06$ & $3,78454 \mathrm{e}-06$ & $-0,7835$ & 0,43346 & \\
\hline ROE & Estimate & StdError & $\mathrm{z}$ value & $\operatorname{Pr}(>|z|)$ & \\
\hline Const & $-0,140824$ & 0,0823995 & $-1,7090$ & 0,08765 & $*$ \\
\hline Total asset turnover & 0,17927 & 0,0941468 & 1,9042 & 0,05708 & $*$ \\
\hline Inventory turnover & $7,08377 \mathrm{e}-05$ & 0,000173794 & 0,4076 & 0,68363 & \\
\hline Accounts receivable turnover & 0,00341809 & 0,00604135 & 0,5658 & 0,57163 & \\
\hline Revenue per employee & $6,02248 \mathrm{e}-05$ & $5,21419 \mathrm{e}-05$ & 1,1550 & 0,24827 & \\
\hline
\end{tabular}

Notes: *** Significant at the 0.01 level,** Significant at the 0.05 level,* Significant at the 0.10 level (two-tailed).

Table 2 presents the research findings of the regression analysis between proxies of efficiency and stock market value. Turnover ratios appeared ineffective in altering some of the ratios most frequently used by equity analysts for the assessment of market value. In particular, although a positive relationship was found between the Total asset turnover ratio and the Market to book ratio, the analysis of this proxy variable showed a contradictory result which does not allow an unambiguous interpretation. In detail, a positive coefficient in relation to Market to book ratio and a negative one in relation to Market to sale ratio were found. Moreover, the other independent variables have an insignificant effect on stock market value, measured by proxies such as the Price to earnings ratio and the Market to sale ratio. In contrast to some published studies based on different firm samples and analysis methodologies (Frijns et al., 2012; Nguyen \& Swanson, 2009; Soliman, 2008; Alan et al., 2014), financial ratios analysis showed that proxies of efficiency and stock market value are largely uncorrelated.

As shown in Table 3, significant relationships between turnover ratios and some proxies of cash flow from operation were found. More specifically, a firm's ability to use its assets efficiently and to determine the optimum credit policy, as suggested respectively by the positive estimate of Total asset turnover and Accounts receivable turnover ratios, is positively correlated with proxies of cash flow. Similarly, the positive estimate of Total asset turnover ratio indicated a firm's ability to cover its total debt with operating cash flow. However, correlations between turnover ratios and Cash flow to account payable revealed ambiguous results. On the one hand, the positive estimate of the Account receivable turnover ratio suggested that the ability to collect money from account receivables allows firms to enhance the coverage of account payable with its operating cash flow. 
On the other hand, as shown by the negative correlation between the Total asset turnover ratio and the Cash flow to account payable, a firm's ability to use its assets efficiently was associated with a reduction of the amount of cash flow compared to its account payables. Taken together, the correlation between proxies of efficiency and Cash flow to account payable suggest that the increase in the amount of account payables is higher than the increment of cash flow that follows a more efficient use of assets, as measured by the Total asset turnover ratio.

Table 2. Stock market value and efficiency

\begin{tabular}{|c|c|c|c|c|c|}
\hline Market to book ratio & Estimate & StdError & $\mathrm{z}$ value & $\operatorname{Pr}(>|z|)$ & \\
\hline Const & 1,20386 & 0,268433 & 4,4848 & $<0,00001$ & $* * *$ \\
\hline Total asset turnover & 0,812568 & 0,310451 & 2,6174 & 0,00896 & $* * *$ \\
\hline Inventory turnover & $-2,50996 \mathrm{e}-05$ & 0,000584614 & $-0,0429$ & 0,96576 & \\
\hline Accounts receivable turnover & 0,0172293 & 0,01982 & 0,8693 & 0,38484 & \\
\hline Revenue per employee & $-0,000209651$ & 0,000167522 & $-1,2515$ & 0,21096 & \\
\hline Price to earnings ratio & Estimate & StdError & $\mathrm{z}$ value & $\operatorname{Pr}(>|z|)$ & \\
\hline Const & 243,274 & 115,07 & 2,1141 & 0,03468 & $* *$ \\
\hline Total asset turnover & $-185,549$ & 133,082 & $-1,3942$ & 0,16346 & \\
\hline Inventory turnover & 0,0268768 & 0,250609 & 0,1072 & 0,91461 & \\
\hline Accounts receivable turnover & $-3,01571$ & 8,49632 & $-0,3549$ & 0,72269 & \\
\hline Revenue per employee & 0,005394 & 0,0718122 & 0,0751 & 0,94014 & \\
\hline Market to sale ratio & Estimate & StdError & $\mathrm{z}$ value & $\operatorname{Pr}(>|\mathrm{z}|)$ & \\
\hline Const & 4,15529 & 0,343893 & 12,0831 & $<0,00001$ & $* * *$ \\
\hline Total asset turnover & $-3,29091$ & 0,397722 & $-8,2744$ & $<0,00001$ & $* * *$ \\
\hline Inventory turnover & $-0,000795075$ & 0,000748956 & $-1,0616$ & 0,28861 & \\
\hline Accounts receivable turnover & 0,0057481 & 0,0253916 & 0,2264 & 0,82094 & \\
\hline Revenue per employee & $3,6786 \mathrm{e}-05$ & 0,000214614 & 0,1714 & 0,86393 & \\
\hline
\end{tabular}

Notes: *** Significant at the 0.01 level, ${ }^{* *}$ Significant at the 0.05 level,* Significant at the 0.10 level (two-tailed).

Table 3. Cash flow and efficiency

\begin{tabular}{|c|c|c|c|c|c|}
\hline Cash flow to assets & Estimate & StdError & $\mathrm{z}$ value & $\operatorname{Pr}(>|z|)$ & \\
\hline Const & 0,020997 & 0,00504581 & 4,1613 & 0,00003 & $* * *$ \\
\hline Total asset turnover & 0,0343688 & 0,00576466 & 5,9620 & $<0,00001$ & $* * *$ \\
\hline Inventory turnover & $1,62336 \mathrm{e}-05$ & $1,06399 \mathrm{e}-05$ & 1,5257 & 0,12729 & \\
\hline Accounts receivable turnover & 0,00109846 & 0,000369866 & 2,9699 & 0,00303 & $* * *$ \\
\hline Revenue per employee & $-5,12776 \mathrm{e}-06$ & $3,19305 \mathrm{e}-06$ & $-1,6059$ & 0,10851 & \\
\hline Cash flow to debt & Estimate & StdError & $\mathrm{z}$ value & $\operatorname{Pr}(>|z|)$ & \\
\hline Const & $-0,756871$ & 0,563608 & $-1,3429$ & 0,17951 & \\
\hline Total asset turnover & 1,7119 & 0,644289 & 2,6570 & 0,00797 & $* * *$ \\
\hline Inventory turnover & 0,000632387 & 0,00120749 & 0,5237 & 0,60055 & \\
\hline Accounts receivable turnover & $-0,0120385$ & 0,0411609 & $-0,2925$ & 0,76996 & \\
\hline Revenue per employee & $7,22911 \mathrm{e}-05$ & 0,000355115 & 0,2036 & 0,83872 & \\
\hline Cash flow to account payable & Estimate & StdError & $\mathrm{z}$ value & $\operatorname{Pr}(>|z|)$ & \\
\hline Const & 0,659461 & 0,0534025 & 12,3489 & $<0,00001$ & *** \\
\hline Total asset turnover & $-0,37361$ & 0,0609696 & $-6,1278$ & $<0,00001$ & $* * *$ \\
\hline Inventory turnover & $2,87114 \mathrm{e}-05$ & 0,000112451 & 0,2553 & 0,79851 & \\
\hline Accounts receivable turnover & 0,0238414 & 0,00390979 & 6,0979 & $<0,00001$ & $* * *$ \\
\hline Revenue per employee & $1,11972 \mathrm{e}-05$ & $3,3747 \mathrm{e}-05$ & 0,3318 & 0,74009 & \\
\hline
\end{tabular}

Notes: *** Significant at the 0.01 level, $* *$ Significant at the 0.05 level,* Significant at the 0.10 level (two-tailed). 
In order to enlarge upon the latter issue, where debts and account payables are involved in the regression analysis of cash flow, we explored the relationships between the most significant proxies of efficiency and some variables relating to firm capital structure. As shown in Table 4, the regression analysis revealed that the greater the Total asset turnover ratio, the higher the amount of Total liabilities to assets ratio. More specifically, the analysis outlined two main results. First, a positive association between the Total asset turnover ratio and the Account payable to total liabilities ratio was found, whilst negative correlations emerged with the Debt to total liabilities and with the Long-term debt to total debt ratios. In other words, statistical evidence suggested that the greater the Total asset turnover ratio, the higher the substitution of debt with account payable. Second, a negative association between Account receivable turnover ratio and the Account payable to total liabilities was found, whilst a positive correlation was revealed with the Debt to total liabilities and Long-term debt to total debt ratios. All other things being equal, in line with findings shown in Table 3, the rise in the Account receivable turnover ratio would lead to a reduction in the amount of account payables and an increase in financial debt. Although these findings need to be interpreted with caution, a plausible explanation for this result might be that the reduction of the account receivables collection period allows firms to pay off account payables more easily and to improve their credit worthiness. A more comprehensive study should examine this issue taking into account the debate about the use of cash flows and its effect on investment and capital structure (to name just a few, Fazzari, Hubbard, \& Petersen, 1988; Kaplan \& Zingales, 1997; Cleary, 1999; Alti, 2003; Almeida, Campello, \& Weisbach, 2004; Becchetti, Castelli, \& Hasan, 2010; Dasgupta, Noe, \& Wang, 2011).

Table 4. Capital structure and efficiency

\begin{tabular}{|c|c|c|c|c|c|}
\hline Total liabilities to assets & Estimate & StdError & $\mathrm{z}$ value & $\operatorname{Pr}(>|z|)$ & \\
\hline Const & 0,586674 & 0,0111611 & 52,5643 & $<0,00001$ & $* * *$ \\
\hline Total asset turnover & 0,0480338 & 0,012422 & 3,8668 & 0,00011 & $* * *$ \\
\hline Inventory turnover & $-1,80033 e-06$ & $7,1172 \mathrm{e}-06$ & $-0,2530$ & 0,80034 & \\
\hline Accounts receivable turnover & $5,74112 \mathrm{e}-05$ & 0,000833609 & 0,0689 & 0,94510 & \\
\hline Account payable to total liabilities & Estimate & StdError & $\mathrm{z}$ value & $\operatorname{Pr}(>|z|)$ & \\
\hline Const & 0,158013 & 0,00797394 & 19,8161 & $<0,00001$ & $* * *$ \\
\hline Total asset turnover & 0,197389 & 0,00886917 & 22,2556 & $<0,00001$ & $* * *$ \\
\hline Inventory turnover & $5,75654 \mathrm{e}-07$ & $5,07798 \mathrm{e}-06$ & 0,1134 & 0,90976 & \\
\hline Accounts receivable turnover & $-0,00485096$ & 0,000594902 & $-8,1542$ & $<0,00001$ & $* * *$ \\
\hline Debt to total liabilities & Estimate & StdError & $\mathrm{z}$ value & $\operatorname{Pr}(>|z|)$ & \\
\hline Const & 0,534258 & 0,0109071 & 48,9827 & $<0,00001$ & $* * *$ \\
\hline Total asset turnover & $-0,145894$ & 0,0121393 & $-12,0183$ & $<0,00001$ & $* * *$ \\
\hline Inventory turnover & $-1,23676 \mathrm{e}-05$ & $6,95524 \mathrm{e}-06$ & $-1,7782$ & 0,07557 & $*$ \\
\hline Accounts receivable turnover & 0,00449869 & 0,000814639 & 5,5223 & $<0,00001$ & $* * *$ \\
\hline Long-term debt to total debt & Estimate & StdError & $\mathrm{z}$ value & $\operatorname{Pr}(>|z|)$ & \\
\hline Const & 0,573848 & 0,0153287 & 37,4362 & $<0,00001$ & $* * *$ \\
\hline Total asset turnover & $-0,164374$ & 0,0170709 & $-9,6289$ & $<0,00001$ & $* * *$ \\
\hline Inventory turnover & $1,38366 \mathrm{e}-05$ & $9,73408 \mathrm{e}-06$ & 1,4215 & 0,15539 & \\
\hline Accounts receivable turnover & 0,011898 & 0,0011391 & 10,4451 & $<0,00001$ & $* * *$ \\
\hline
\end{tabular}

Notes: *** Significant at the 0.01 level, ${ }^{* *}$ Significant at the 0.05 level,* Significant at the 0.10 level (two-tailed).

\section{Concluding Remarks}

This paper has investigated the relationships between proxies of efficiency, measured by several turnover ratios, and firm profitability, stock market value and operational cash flow. Explanatory variables of firm capital structure were also analyzed to examine more closely correlations between efficiency and cash flow. The purpose of this study was to outline whether the analysis of financial ratios, used as proxies of efficiency, can help investors and equity analysts to obtain information on firm performances on the basis of one of the most widely used methodologies, namely the multiple regression model.

On a sample of 1,935 firm-year observations related to 215 Italian non-financial listed companies between 2004 
and 2013, regression results show that expectations about positive associations between the above mentioned proxy variables are partially confirmed as regards the relationship between proxies of efficiency and some firm profitability indicators more closely connected to operating activities and various measures of operational cash flow. Research findings did not provide unambiguous results about correlations between proxies of efficiency and ratios of stock market prices. In particular, this study revealed three main findings.

First, the most significant associations were found between proxies of efficiency (Total asset turnover, Accounts receivable turnover and Inventory turnover ratio) and measures of profitability that are more directly related to firm operating activities such as EBITDA to assets ratio. The correlation weakened for other proxies of profitability such as ROA and ROE.

Second, strong correlations have been revealed between some proxies of efficiency (Total asset turnover and Accounts receivable turnover ratio) and measures of cash flow. A further examination of this issue has also shown that turnover ratios are correlated with components of firm capital structure. Aware of the caution that is needed for the interpretation of these research findings, the regression results suggested that the greater the Total asset turnover, the higher the substitution of debt with account payable. It was also found that an increase in Accounts receivable turnover allows firms to reduce account payables and to enhance financial debts.

Third, this research has shown that associations between turnover ratios and proxies of stock market value were not significant and Revenues per employee did not have any explanatory power.

The findings of this study have several important implications. First, the evidence provides investors and equity analysts with some insight into the relevance of efficiency ratios in the evaluation of firm performances. Accounting information is commonly used on the basis of the regression model by investors in their decision process and by analysts when recommending a stock. Other implications concern the firm compensation policy and organizational performance measurements. For example, these findings may help firms to analyze how pay structures and pay levels can relate to efficiency. However, some limitations need to be considered. First, this study is limited to Italian listed companies and consequently by sample size. Moreover, the study fails to address how industry variables could affect the relationship between efficiency and firm profitability due to the small number of firms for each industry. A further study with more focus on this issue is therefore suggested.

\section{References}

Abdolmohammadi, M., Simnett, R., Thibodeau, J. C., \& Wright, A. M. (2006). Sell-Side Analysts' Reports and the current external reporting model. Accounting Horizons, 20(4), 375-389. http://dx.doi.org/10.2308/acch.2006.20.4.375

Akhigbe, A., \& McNulty, J. (2005). Profit efficiency sources and differences among small and large U.S. commercial banks. Journal of Economics and Finance, 29(3), 289-299. http://dx.doi.org/10.1007/BF02761575

Alam, I. M. S., \& Sickles, R. C. (1998). The relationship between stock market returns and technical efficiency innovations: Evidence from the US airline industry. Journal of Productivity Analysis, 9(1), 35-51. http://dx.doi.org/10.1023/A:1018368313411

Alan, Y., Gao, G. P., \& Gaur, V. (2014). Does inventory productivity predict future stock returns? A retailing industry perspective. Management Science, 60(10), 2416-2434. http://dx.doi.org/10.1287/mnsc.2014.1897

Almeida, H., Campello, M., \& Weisbach, M. S. (2004). The Cash Flow Sensitivity of Cash. Journal of Finance 59(4), 1777-1804. http://dx.doi.org/10.1111/j.1540-6261.2004.00679.x

Alti, A. (2003). How sensitive is investment to cash flow when financing is frictionless? Journal of Finance, 58(2), 707-722. http://dx.doi.org/10.1111/1540-6261.00542

Baik, B., Chae, J., Choi, S., \& Farber, D. B. (2013). Changes in operational efficiency and firm performance: a frontier analysis approach. Contemporary Accounting Research, 30(3), 996-1026. http://dx.doi.org/10.1111/j.1911-3846.2012.01179.x

Barr, R., Killgo, K. A., Siems, T. F, \& Zimmel, S. (2002). Evaluating the Productive Efficiency and Performance of U.S. Commercial Banks. Managerial Finance, 28(8), 3-25. http://dx.doi.org/10.1108/03074350210767988

Becchetti, L., \& Sierra, J. (2003). Bankruptcy risk and productive efficiency in manufacturing firms. Journal of Banking \& Finance, 27, 2099-2120. http://dx.doi.org/10.1016/S0378-4266(02)00319-9

Becchetti, L., Castelli, A., \& Hasan, I. (2010). Investment-cash flow sensitivities, credit rationing and financing 
constraints in small and medium-sized firms. Small Business Economics, 35(4), 467-497. http://dx.doi.org/10.1007/s11187-008-9167-1

Berger, A. N., \& Bonaccorsi di Patti, E. (2006). Capital structure and firm performance: A new approach to testing agency theory and an application to the banking industry. Journal of Banking \& Finance, 30, 1065-1102. http://dx.doi.org/10.1016/j.jbankfin.2005.05.015

Berger, A. N., \& Mester, L. J. (1997). Inside the black box: What explains differences in the efficiencies of financial institutions? Journal of Banking \& Finance, 21, 895-947. http://dx.doi.org/10.1016/S0378-4266(97)00010-1

Berger, A., \& Humphrey, D. B. (1997). Efficiency of financial institutions: International survey and directions for future research. European Journal of Operational Research, 98(2), 175-212. http://dx.doi.org/10.1016/S0377-2217(96)00342-6

Bouwman, M. J., Frishkoff, P., \& Frishkoff, P. A. (1995). The relevance of GAAP-Based information: a case study exploring some uses and limitations. Accounting Horizons, 9(4), 22-47.

Breton, G., \& Taffler, R. J. (2001). Accounting information and analyst stock recommendation decisions: a content analysis approach. Accounting and Business Research, 31(2), 91-101. http://dx.doi.org/10.1080/00014788.2001.9729604

Cleary, S. (1999). The relationship between firm investment and financial status. Journal of Finance, 54(2), 673-692. http://dx.doi.org/10.1111/0022-1082.00121

Cummins, J. D., \& Xie, X. (2009). Market values and efficiency in US insurer acquisitions and divestitures. Managerial Finance, 35(2), 128-155. http://dx.doi.org/10.1108/03074350910923482

Dasgupta, S., Noe, T. H., \& Wang, Z. (2011). Where did all the dollars go? The effect of cash flows on capital and asset structure. Journal of Financial and Quantitative Analysis, 46(5), 1259-1294. http://dx.doi.org/10.1017/S0022109011000512

Demerjian, P., Lev, B., \& McVay, S. (2012). Quantifying managerial ability: a new measure and validity tests. Management Science, 58(7),1229-1248. http://dx.doi.org/10.1287/mnsc.1110.1487

Fairfield, P. M., \& Yohn, T. L. (2001). Using Asset Turnover and Profit Margin to forecast changes in profitability. Review of Accounting Studies, 6, 371-385. http://dx.doi.org/10.1023/A:1012430513430

Farrell, M. J. (1957). The measurement of productive efficiency. Journal of the Royal Statistical Society. Series A (General), 120(3), 253-290. http://dx.doi.org/10.2307/2343100

Fazzari, S. M., Hubbard, G. R., \& Petersen, B. C. (1988). Financing constraints and corporate investment. Brooking Papers on Economic Activity, 141-195.http://dx.doi.org/10.2307/2534426

Frijns, B., Margaritis, D., \& Psillaki, M. (2012). Firm efficiency and stock returns. Journal of Productivity Analysis, 37, 295-306. http://dx.doi.org/10.1007/s11123-011-0246-y

Gaganis, C., Hasan, I., \& Pasiouras, F. (2013). Efficiency and stock returns: evidence from the insurance Industry. Journal of Productivity Analysis, 40, 429-442. http://dx.doi.org/10.1007/s11123-013-0347-x

Greene, W. H., \& Segal, D. (2004). Profitability and efficiency in the U.S. life insurance industry. Journal of Productivity Analysis, 21, 229-247. http://dx.doi.org/10.1023/B:PROD.0000022092.70204.fa

Gupta, M. C., \& Huefner, R. J. (1972). A cluster analysis study of financial ratios and industry characteristics. Journal of Accounting Research, 10(1), 95-77. http://dx.doi.org/10.2307/2490219

Habib, M. A., \& Ljungqvist, A. (2005). Firm value and managerial incentives: a stochastic frontier approach. Journal of Business, 78(6), 2053-2093. http://dx.doi.org/10.1086/497040

Halkos, G. E., \& Tzeremes, N. G. (2007). Productivity efficiency and firm size: an empirical analysis of foreign owned companies. International Business Review, 16, 713-731. http://dx.doi.org/10.1016/j.ibusrev.2007.06.002

Jansen, I., Ramnath, S., \& Yohn, T. (2012).A Diagnostic for earnings management using changes in asset turnover and profit margin. Contemporary Accounting Research, 29(1) 221-251. http://dx.doi.org/10.1111/j.1911-3846.2011.01093.x

Jiang, K., \& Wang, S. (2009). Firms in economic distress: survival strategies and economic factors (pp. 1-40). Retrieved from http://ssrn.com/abstract $=1465181$ 
John, R., Lang, L. H. P., \& Netter, J. (1992). The voluntary restructuring of large firms in response to performance decline. The Journal of Finance, 47(3), 891-917. http://dx.doi.org/10.1111/j.1540-6261.1992.tb03999.x

Kang, J. K., \& Shivdasani, A. (1997). Corporate restructuring during performance declines in Japan. Journal of Financial economics, 46, 29-65. http://dx.doi.org/10.1016/S0304-405X(97)00024-X

Kaplan, S. N., \& Zingales, L. (1997). Do investment-cash flow sensitivities provide useful measures of financing constraints? Quarterly Journal of Economics, 112(1), 169-215. http://dx.doi.org/10.1162/003355397555163

Koli, L. N., \& Rawat, B. (2011). Measuring of operational efficiency and its impact on overall profitability. A Case Study of BPCL.BVIMR Management Egde, 4(2), 105-114.

Koopmans, T. C. (1951). An analysis of production as an efficient combination of activities. In T.C. Koopmans (Ed.), Activity Analysis of Production and Allocation, Cowles Commission for Research in Economics. New York: Wiley and Sons.

Kothari, S. P. (2001). Capital markets research in accounting. Journal of Accounting and Economics, 31, 105-231. http://dx.doi.org/10.1016/S0165-4101(01)00030-1

Kwak, J. K. (2013). Information technology implementation and operational efficiency. Management Science and Financial Engineering, 19(2), 13-18. http://dx.doi.org/10.7737/MSFE.2013.19.2.013

Leibenstein, H. (1966). Allocative efficiency vs "X-efficiency". The American Economic Review, 56(3), 392-415.

Lev, B., \& Thiagarajan, S. R. (1993). Fundamental Information Analysis. Journal of Accounting Research, 31(2), 190-215. http://dx.doi.org/10.2307/2491270

Makridakis, S., Wheelwright, S. C., \& Hyndman, R. J. (1998). Forecasting, methods and applications. Hoboken, NJ: John Wiley and Sons.

Margaritis, D., \& Psillaki, M. (2007). Capital Structure and Firm Efficiency. Journal of Business Finance \& Accounting, 34(9) \& (10), 1447-1469. http://dx.doi.org/10.1111/j.1468-5957.2007.02056.x

Nguyen, G. X., \& Swanson, P. E. (2009). Firm characteristics, relative efficiency, and equity returns. Journal of Financial and Quantitative Analysis, 44(1), 213-236. http://dx.doi.org/10.1017/S0022109009090012

Nissim, D., \& Penman, S. H. (2001). Ratio analysis and equity valuation: From research to practice. Review of Accounting Studies, 6, 109-154. http://dx.doi.org/10.1023/A:1011338221623

Norvaisiene, R. (2012). The Impact of Capital Structure on the Performance Efficiency of Baltic Listed Companies. Inzinerine Ekonomika-Engineering Economics, 23(5), 505-516. http://dx.doi.Org/10.5755/j01.ee.23.5.1979

Robbins, D. K., \& Pearce II, J. A. (1992). Turnaround: retrenchment and recovery. Strategic Management Journal, 13, 287-309. http://dx.doi.org/10.1002/smj.4250130404

Rogers, R. K., \& Grant, J. (1997). Content analysis of information cited in reports of sell-side financial analysts. Journal of Financial Statement Analysis, 3(1), 17-30.

Soliman, M. T. (2008). The use of DuPont analysis by market participants. The Accounting Review, 83(3), 823-853. http://dx.doi.org/10.2308/accr.2008.83.3.823

Sudarsanam, S., \& Lai, J. (2001). Corporate financial distress and turnaround strategies: an empirical analysis. British Journal of Management, 12, 183-199. http://dx.doi.org/10.1111/1467-8551.00193

Talluri, S., Kim, M. K., \& Schoenherr, T. (2013). The relationship between operating efficiency and service quality: are they compatible? International Journal of Production Research, 51(8), 2548-2567. http://dx.doi.org/10.1080/00207543.2012.737946

\section{Copyrights}

Copyright for this article is retained by the author(s), with first publication rights granted to the journal.

This is an open-access article distributed under the terms and conditions of the Creative Commons Attribution license (http://creativecommons.org/licenses/by/3.0/). 